Original article

\title{
RISK AS A FACTOR OF DECISION MAKING IN PROJECTS FINANCING OF INFRASTRUCTURE PROJECTS
}

\author{
Jelena Jovanović ${ }^{1}$, Marija Mosurović ${ }^{2}$ Ivana Berić3
}

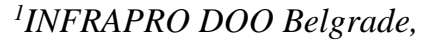
Serbia

${ }^{2}$ University of Belgrade, Institute Mihajlo Pupin, Serbia

${ }^{3}$ EDUCONS University, Faculty for Project and Innovation Management, Serbia
\end{abstract}

Received:8 December 2020 Revised: 15 December 2020 Accepted: 22 December 2020

\section{INTRODUCTION}

Project finance, as a specific form of current practice financing, presents an increasingly more common global way of financing large investments projects which demand high capital investments and whose building up and exploitation period is very long. With such investments, project finance has a range of advantages if compared with classical corporate loans. It's enabling cost-effective execution of a project lacking in financial funds for construction. Project financing can especially have a significant role in the development of large infrastructure projects that are desperately needed, especially in countries in development. However, considering that these projects are very complex and that their realization and exploitation periods are very long, it goes without saying that the capital expenses are higher and that more time is needed to make a decision about funding such projects. What infrastructure projects have in common is long duration and complexity in a technical, financial and legal sense, which causes a whole range of risks. A basic characteristic of project financing is that the income is expected from the project-generated profit. This is the reason why project financing is undertaken only if it can be assessed that the project will be rentable and that it will create sufficient monetary flows to repay the debt (Finnerty, 2013).

Infrastructure projects are under general project risks but also other particular risks concerning the project cost, schedule, quality, performance, health and safety aspects,

Corresponding author. Email: marija.mosurovic@pupin.rs

ISSN 2560-4961 (online)

Copyright (C) 2020, The Authors. Published by IPMA Serbia.

This is an open access article under the CC BY-NC 4.0 license (https://creativecommons.org/licenses/bync/4.0/)

Doi: $10.18485 /$ epmj.2020.10.2.2 
environmental aspects, as well as with other, non-tangible factors (Mikić et al., 2013) . From the aspect of project financing, the key thing when analyzing infrastructure projects is highquality projection of expected cash- flow of the project, as well as an assessment of potential risks which can more or less influence future monetary flows. For this reason, risk analysis of infrastructure projects, which is taken with the aim of gaining an insight into future events which can impact investment behavior, is an important factor for making decisions about project financing. Additionally, adequate risk management presents an important element for a successful realization of a specific project that, by exploiting it, should pay off the invested funds (Rihar et al., 2019; Wang et al., 2016). Risks may have possible both positive and negative impacts on project goals. Beside that stakeholder perception is important in the sense of determination of level of traditional project delivery achievement influenced by different stakeholders (Rafindadi et al., 2014).

Project financing is currently developed in Serbia mostly within residential and commercial infrastructure, whose purpose is further sale and rent. Project financing of infrastructure projects is not sufficiently presented. Nevertheless, with the development of public-private partnership, there are new projects and concessions, whose realization is expected in the future. Having in mind an imperative need for infrastructure projects realization, along with the fact that a great number of projects is not conducted according to the planned pace and within the planned budget, which significantly influences the project sustainability and future monetary flows it will generate, a problem regarding foreign investors wanting to finance such projects is presented.

A question arises: what are the most common risks that follow infrastructure projects? With the aim of increasing infrastructure projects realization success rate and their rentability, as a prerequisite for making a decision about project financing, this paper presents a conducted empirical research in Serbia about infrastructure project key risk factors, about a possibility of foreseeing them in the preparatory project phases, as well as the level of practical technique and tool applications when managing risks. The results indicate 12 significant deviations when executing infrastructure projects, low level of practical risk management techniques application and, consequently, a low possibility of predicting projects risks during infrastructure projects preparations.

The results can be of use to all participants in infrastructure projects, and especially to the participants in preparation phase of such projects (investors, public institutions, financial institutions, architecture companies companies) as well as company managers, project managers and risk managers.

\section{MAKING DECISIONS ABOUT PROJECT FINANCE}

Since the early 1980s, project financing for large infrastructure projects has experienced a dramatic revival. Managing risks of these projects is a very challenging task and it includes organizing and shifting the various project risks to those parties that are best able to appraise and control them (Brealey et al., 1996; Torrisi, 2009).

Project financing should be judged only by its ability to be able to generate support and cash (Craciun, 2011). Within the same lines, creditworthiness grading of a potential debtor does not weigh much when making decisions about project finance (as it is in the case with classical loans), and especially when for undergoing project is formed by a particular special, newly founded company which practically does not have any historical data of its business.

Making decisions about financing a specific project implies that the project is technically doable and financially cost-efficient. An analysis of the project economic power is essential, whether the project is viewed from an investor's or financer's point of view. Finance institutions are also hiring engineers and other experts that can perform project rentability analysis. Complex projects bring along numerous risks, whose effects could have a considerable influence on a project rentability. In order to make the project acceptable for financers, it is paramount to elaborate it in such a way that it consists of supply and demand market analysis, technical and technological analysis, and capability analysis of investors to 
carry out the project and repay the debt. From the aspect of financial and economic analysis and project finance risk analysis, i.e. it is essential to conduct a project feasibility study.

The content of these studies is defined in Serbia by the Code of content and scope of previous works, previous feasibility study and feasibility study (Government of the Republic of Serbia, 2012) with the aim of allowing a better quality approach in planning and undertaking future investments. Therefore, if a project is not financially cost-effective, it doesn't mean that there isn't at the same time validity for its launch. Projects such as most infrastructure projects or non-economic projects in health and education fields mostly have a low rate of financial rentability, and yet are of great significance to the community, so it is impossible to provide a verification grade for such projects solely on the basis of financial parameter without considering effects which project will have on the whole society regarding achievement strategic aims, economy development, possible savings, public services quality, ecology and environmental protection and so on. Public funding is necessary for such projects, i.e. financing from the state budget, donations or subventions such as tax relief, price controls, a more affordable import policy etc. When assessing such projects, it is necessary to apply socially verified prices. We deal then with a sociable-economic project rentability grade.

\section{INFRASTRUCTURE PROJECTS RISK CLASSIFICATION}

Managing risks on a project level has to be strategically organized and to involve steps of risk monitoring and risk control (PMI, 2009). Risks can be classified into business and clean risks, where by business risks we mean risks that are constantly present in business operation and relate to risks during business operations and profit maximizing and/or loss minimizing, while clean risks relate to a possibility of a negative impact and loss realization (Petrović et al., 2010). Clean risks are then classified into ones that can cause a direct loss of asset, indirect loss of asset, liability loss and personal loss. According to the second classification, the same authors classify risks into familiar ones, i.e. risks we are aware of, and unfamiliar ones, i.e. risks that we cannot foresee and that are not previously known (Petrović et al., 2010). Infrastructure projects that include complex infrastructure works carry along a significant number of risks, considering that infrastructure sector is probably the one mostly exposed to risks. Classification of risks can be done in many ways: depending on cause of its occurrence, project phase where they occur, their predictability, material consequences etc. The risk is, of course, unique to every single project and every participant in the project.

Bunni (2003) has provided the most comprehensive risk classification on projects in infrastructure, which can be considered reliable for infrastructure projects:

- Geographical classification - the country where project employees work and its risks, considering that projects are often run away from its native environment. This group encompasses risks such as a new culture, customs, methodologies, different policies, exchange rate variation and so on.

- Classification based on size and complexity of the project- project growth and the increase of its complexity does not bring to the linear risk increase in size, yet new special risks appear that must be identified and taken into consideration before launching the project.

- Classification according to the legal concept - legal concept accepted in the jurisdiction where the project is run leads to certain risks, thus creating four significant areas: contract; tort; equity or custom- depending from the part of the world, legislation (statutes).

- Classification according to the effect produced by the risk eventuating, where they occur chronologically within the project, risks can be divided into the ones that happen prior to the beginning of the construction (the phase of forming project concept, research and projecting); during construction; after construction (after the handover of the object, opening to business, during project exploitation).

- Classification in construction contractsspecific risks allocation according parties in the contact. 
Craciun (2011) singled out Goshal's risk classification as the most famous one:

- Macroeconomic risks - that are not under the company control and that are caused by political, natural and financial factors;

- Regulatory risks - risks that can be partially influenced by the company and whose effect can be ameliorated by company's activity. These risks include the change of legal regulations influencing certain business aspects, such as the legislature, tax regulations and so on.

- Risks related to competition - risk related to the market and all the activities that influence or are influenced by the market, such as competition.

- Risks related to resources or access to resources - risks that the company bears by its strategy choice that includes availability of certain resources such as natural, financial, human resources and so on.

\section{INFRASTRUCTURE PROJECT RISKS IN SERBIA}

This paper will illustrate empirical study results that relate to the risk analysis of infrastructure projects in Serbia. Experts from several companies, who have been hired for infrastructure projects in Serbia, have been contacted. Considering there was a risk of a low number of replies, as well as the likelihood that the level of practical risk management in Serbia and Serbian companies is not high, as an addition to the gathered sample, we have contacted experts hired on infrastructure projects abroad or in foreign companies, i.e. companies whose headquarters are not in the Republic of Serbia. Experts with experience in infrastructure have been contacted (directly and indirectly). The subjects were given a list of 30 key risks that infrastructure projects are exposed to, so as to provide their answers to the question whether the stated risks happened on a specific project they were hired for, and how much the influence of the risks was on the planned development of the project.

This is how we identified most common risks on infrastructure projects: insufficiency in project-technical documentation, legal risks in the country where the project is run, unpredictably difficult weather conditions and deficiencies in previous works. Over $70 \%$ of the subjects declared that these risks happened on an actual project they were hired for. Table no. 1 shows a list of ten risks that are most common according to the subjects' responses. The division was done according to chronological emergence of the risks.

Table 1: Most common risks on infrastructure projects

\begin{tabular}{|l|c|c|}
\hline Risk & $\begin{array}{c}\text { No risk } \\
\text { emergence }\end{array}$ & $\begin{array}{c}\text { Risk } \\
\text { emergence }\end{array}$ \\
\hline $\begin{array}{l}\text { Flaws in project- } \\
\text { technical } \\
\text { documentation }\end{array}$ & $17 \%$ & $83 \%$ \\
\hline $\begin{array}{l}\text { Legal risks in the } \\
\text { country where the } \\
\text { project is run }\end{array}$ & $26 \%$ & $74 \%$ \\
\hline $\begin{array}{l}\text { Unpredictably } \\
\text { difficult weather } \\
\text { conditions that } \\
\text { prevent } \\
\text { construction works }\end{array}$ & $28 \%$ & $72 \%$ \\
\hline $\begin{array}{l}\text { Insufficiencies in } \\
\text { previous works }\end{array}$ & $30 \%$ & $70 \%$ \\
\hline $\begin{array}{l}\text { Contract-related } \\
\text { issues }\end{array}$ & $32 \%$ & $68 \%$ \\
\hline $\begin{array}{l}\text { Poor organization } \\
\text { of the } \\
\text { contractor/subcontr } \\
\text { actor }\end{array}$ & $34 \%$ & $66 \%$ \\
\hline $\begin{array}{l}\text { Unpredictable } \\
\text { underground } \\
\text { conditions }\end{array}$ & $36 \%$ & $64 \%$ \\
\hline $\begin{array}{l}\text { Lack of or } \\
\text { inadequate } \\
\text { resources }\end{array}$ & $40 \%$ & $58 \%$ \\
\hline $\begin{array}{l}\text { Flaws in work } \\
\text { quality }\end{array}$ & $64 \%$ \\
\hline Political risk & & \\
\hline
\end{tabular}

According to subjects' responses, every offered risk happened in a smaller or larger extent on one of the projects that were the subject of research. Besides, only two subjects (4\%) stated that none of the offered risks happened on the projects they were hired for. Both of the subjects belong to a group that claimed that their project is carried out in accordance with the planned dynamics and within the planned budget.

In order to evaluate the influence of the risks offered in the questionnaire to the project realization, i.e. planned dynamics, cost and 
profit of the project exploitation, a qualitative scale of given options is turned into numerical one, as shown in Table no. 2.

Table 2: Influence of specific risks on the infrastructure project planned realization

\begin{tabular}{|c|c|c|}
\hline No. & RISK & $\begin{array}{l}\text { Influence } \\
\text { on planned } \\
\text { realization } \\
\text { - total } \\
\text { value } \\
\text { calculated }\end{array}$ \\
\hline & General risks & \\
\hline 1 & Soil risk & 16.50 \\
\hline 2 & Political risks & 17.00 \\
\hline 3 & Financial market risks & 11.00 \\
\hline 4 & $\begin{array}{l}\text { Legal risk of the country } \\
\text { where the project is run }\end{array}$ & 21.75 \\
\hline 5 & Project development risk & 14.00 \\
\hline 6 & Corruption & 13.50 \\
\hline & $\begin{array}{l}\text { Conception creation and } \\
\text { projection phase }\end{array}$ & \\
\hline 7 & Flaws in previous works & 19.00 \\
\hline 8 & $\begin{array}{l}\text { Flaws in project-technical } \\
\text { documentation }\end{array}$ & 24.50 \\
\hline 9 & $\begin{array}{l}\text { Unpredictable underground } \\
\text { conditions }\end{array}$ & 17.00 \\
\hline & Execution phase & \\
\hline 10 & Contract-related issues & 20.25 \\
\hline 11 & $\begin{array}{l}\text { Health and safety at work } \\
\text { problems }\end{array}$ & 5.00 \\
\hline 12 & $\begin{array}{lr}\text { Unpredictably } & \begin{array}{r}\text { difficult } \\
\text { weather }\end{array} \\
\text { impeding } & \text { conditions } \\
\text { works } & \\
\end{array}$ & 17.50 \\
\hline 13 & Lack or inadequate resource & 14.25 \\
\hline 14 & $\begin{array}{l}\text { Market risks during } \\
\text { construction }\end{array}$ & 10.50 \\
\hline 15 & Flaws in work quality & 12.75 \\
\hline 16 & $\begin{array}{l}\text { Lack of financial means for } \\
\text { project realization }\end{array}$ & 11.00 \\
\hline 17 & Credit risks & 5.25 \\
\hline 18 & $\begin{array}{l}\text { Inadequate control and } \\
\text { support from } \\
\text { manager/engineer, } \\
\text { incompetence of } \\
\text { manager/engineer }\end{array}$ & 17.50 \\
\hline 19 & $\begin{array}{l}\text { Problems regarding } \\
\text { execution technology }\end{array}$ & 7.50 \\
\hline 20 & $\begin{array}{l}\text { Poor } \\
\text { contractor/subcontractor } \\
\text { organization }\end{array}$ & 17.25 \\
\hline 21 & $\begin{array}{l}\text { Environmental protection } \\
\text { risks }\end{array}$ & 4.25 \\
\hline \multirow[t]{2}{*}{22} & Force majeure & 5.25 \\
\hline & Exploitation phase & \\
\hline 23 & $\begin{array}{l}\text { Exceeded costs of managing } \\
\text { constructed object }\end{array}$ & 12.50 \\
\hline
\end{tabular}

\begin{tabular}{|c|l|c|}
\hline 24 & $\begin{array}{l}\text { Withholding various work } \\
\text { permits in exploitation } \\
\text { project phase }\end{array}$ & 11.75 \\
\hline 25 & $\begin{array}{l}\text { Market risk related to the } \\
\text { project input during } \\
\text { exploitation }\end{array}$ & 8.50 \\
\hline 26 & $\begin{array}{l}\text { Market risk related with the } \\
\text { demand of the project } \\
\text { product during projects } \\
\text { exploitation }\end{array}$ & 8.25 \\
\hline 27 & $\begin{array}{l}\text { Tariff change } \\
28\end{array}$ & $\begin{array}{l}\text { Payment claim risks by } \\
\text { users }\end{array}$ \\
\hline 29 & Technological risk & 6.00 \\
\hline 30 & Competitive risk & 5.25 \\
\hline
\end{tabular}

Data presented in Table 1 and Table 2 indicate that the subjects consider the following risks as the ones of the greatest influence on planned project realization: flaws in project-technical documentation, legal risks of the country where the project is run, contract-related problems, flaws in previous works, unpredictably difficult weather conditions, inadequate control and support by a manager, poor contractor/subcontractor organization etc. These risks greatly overlap with the risks that, according to the subjects' responses and the gathered results, are identified as the most common ones in infrastructure projects. The overlap of the data is logical for a questionnaire formed in this manner, and for a data analysis performed in this way, considering that the calculated value of a risk influence on a planned realization of a project directly conditioned by a number of replies offered on a qualitative scale, and that the number of responses is the largest for the risks that have been identified as the most common ones. Moreover, data from the tables confirm that each of the stated risks has had a significant influence on the planned project flow.

\section{CONCLUSION}

The significance of cost and benefit analysis is used more frequently on a European Union level in order to grade social-economic reasons for starting large projects (Stančić, \& Čupić, 2015). Making a decision about infrastructure project financing is not only significant from the point of view of an institution, but it also has a wider social significance. Infrastructure projects have a wide range for social impacts and they include risks that are connected with public sector activities, and lastly, these types 
of projects have environmental consequences of operations (Craciun, 2011; Rihar et al., 2019).

Taking all of this into consideration, together with the knowledge gained by the questionnaire, here are the following recommendations for investors, public institutions, financial institutions, contractor companies, project developers, company management, project managers, risk managers:

- More time and resource is necessary to be invested in planning phase of infrastructure projects, since the risk of flaws in project-technical documentation presents the key risk of such projects (considering the number of occurrences and the level of planned project realization). This level impacts significantly on delays construction of objects, higher costs, and consequently rentability and cost-efficiency of projects for project financing.

- In order to increase the possibility of predicting possible risks, and the proper response to these risks, it is essential to raise awareness of organization managers who take part in the infrastructure projects about the needs of risk management usage, in addition to educating employees hired in these projects, especially in the planning phase.

- Infrastructure project financing in Serbia is not on a satisfying level, greatly because investment in such projects presents a risk for potential investors. The level of risk exposure can be decreased by using adequate risk management skills. Investors and financial institutions can have a common role in educating employees in public institutions that participate in infrastructure projects preparations, as well as in educating other participants in project realization. This form of cooperation would bring not only to a more successful realization of infrastructure projects but also to motivating investors to invest in infrastructure.

- The introduction of more specific legal framework for managing risks and setting up process standards when managing risks in companies that are involved in infrastructure projects can contribute to raising the practical application level of risk management and to a more successful realization of infrastructure projects.

None of the risks that have been identified on the market as the most common ones, or as risks with the greatest impact on a planned project realization, does not belong to the risk group in the project exploitation phase.

\section{ACKNOWLEDGEMENTS}

The research presented in this paper is funded by the Serbian Ministry of Education, Science and Technological Development of the Republic of Serbia.

\section{REFERENCES}

Brealey, R. A., Cooper, I. A., \& Habib, M. A. (1996). Using Project Finance to Fund Infrastructure Investments. Journal of Applied Corporate Finance. https://doi.org/10.1111/j.17456622.1996.tb00296.x

Bunni, N. G. (2003). Risk and insurance in construction, second edition. In Risk and Insurance in Construction. https://doi.org/10.4324/9780203476543

Craciun, M. (2011). A New Type of Risk in Infrastructure Projects. Modern Economy. https://doi.org/10.4236/me.2011.24053

Finnerty, J. D. (2013). Project Financing; Asset-Based Financial Engineering. In Information Sciences.

Government of the Republic of Serbia. (2012). Rulebook on the content and scope of previous works, previous feasibility studies and feasibility studies. Official Gazette, 1.

Mikić, M., Petojević, Z., \& Ivanišević, N. (2013). Critical Risks in Serbian Infrastructure Projects. 11th International Conference: Organization, Technology and Management in Construction. Dubrovnik, Croatia.

Petrović, D., Jovanović, P., \& Raković, R. (2010). Upravljanje projektnim rizicima. Udruženje za upravljanje projektima 
Srbije.

PMI. (2009). Practice Standard for Project Risk Management. In Project Management Institute, Inc. (PMI).

Rafindadi, A. D., Mikić, M., Kovačić, I., \& Cekić, Z. (2014). Global Perception of Sustainable Construction Project Risks. Procedia - Social and Behavioral Sciences. https://doi.org/10.1016/j.sbspro.2014.03. 051

Rihar, L., Žužek, T., Berlec, D., \& Kušar, J. (2019). Standard Risk Management Model for Infrastructure Projects. https://doi.org/10.5772/intechopen.8338 9

Stančić, P., \& Čupić, M. (2015). Socioeconomic Analysis of Projects According to the European Union
Methodology. In M. Milena Jakšić, V. Stojanović Aleksić, \& P. Mimović (Eds.), Economic and Social Aspects of Serbia Accession to the EU. University of Kragujevac, Faculty of Economics.

Torrisi, G. (2009). Public Infrastructure: Definition, Classification and Measurement Issues. In Economics, Management, and Financial Markets.

Wang, T., Wang, S., Zhang, L., Huang, Z., \& Li, Y. (2016). A major infrastructure riskassessment framework: Application to a cross-sea route project in China. International Journal of Project Management. https://doi.org/10.1016/j.ijproman.2015. 12.006 